\title{
The Acquisition and Handling of News on the French Wars of Religion: The Case of Hermann Weinsberg
}

\author{
Alexandra Schäfer \\ The Circulation of News on the French Wars of Religion
}

The French Wars of Religion (1562-98) were one of the central conflicts in Europe in the period of confessionalisation. They received an enormous amount of attention in news media in France as well as in neighbouring countries. News on the wars circulated Europe-wide, orally, in handwritten and in printed form: French prints, translations or compendiums, spread across Europe in the form of polemics, declarations, poems, copies of letters, portraits, allegories and plays, to name only a few genres. ${ }^{1}$

In the Holy Roman Empire, there was a vast amount of news available, circulating in letters, handwritten avvisi, printed broadsheets and pamphlets, in addition to the oral news brought by travellers, city messengers, private couriers and postal employees at the end of the sixteenth century. ${ }^{2}$ But how was this news received, handled, adopted and reworked?

Sources on these practical aspects of readership in the late sixteenth century are rare, but they do exist. ${ }^{3}$ One of these exceptional cases is that of the councillor Hermann Weinsberg in Cologne, who eagerly reported on the ongoing contemporary events in his diary-like Gedenkbücher (commemorative books). Weinsberg wrote about the process of news acquisition, the reliability of different channels

1 News is here defined as information with a specific quality (up-to-dateness, media transmission, publicity). Cf. Alphons Silbermann, Handbuch der Massenkommunikation und Medienforschung, vol. 2 (Berlin: Volker Spiess, 1982), p. 319.

2 There is currently no comprehensive study of the Empire's news on the French Wars of Religion. My PhD thesis on the circulation of printed news publications on the French Wars of Religion in the Empire, with particular focus on $1588-9$, is in preparation and will be a first step towards filling this gap.

3 For an overview on this type of sources in the German context: Gabriele Jancke et al., Selbstzeugnisse im deutschsprachigen Raum. Autobiographien, Tagebücher und andere autobiographische Schriften 1400-1620 [2012], <www.geschkult.fu-berlin.de/e/jancke-quellenkunde/ index.html> [18/9/13].

(C) ALEXANDRA SCHÄFER, 2016 | DOI 10.1163/9789004277199_031

This is an open access chapter distributed under the terms of the Creative Commons Attribution-

Noncommercial-NoDerivatives 3.o Unported (CC-BY-NC-ND 3.0) License. 
and media, the importance assigned to certain events, their representation in the media, and the reasons for his interest in particular news. Therefore, he is a valuable source concerning the purchase, handling, framing and reworking of news. While Weinsberg's writings have already been examined in various research projects, his relation to news is a subject hitherto neglected. ${ }^{4}$

After a short discussion of Weinsberg and the Gedenkbücher, this chapter will examine which different channels of communication Weinsberg used, which characteristics he assigned to them, which news he took note of in his Gedenkbücher on the French Wars of Religion and the reasons for the selection he made as he recorded them. On some occasions Weinsberg purchased printed news by the Cologne engraver, printer and publisher Franz Hogenberg, who is the sole example for contemporary, regular visual news publications in the Empire throughout the whole period of the French Wars of Religion. Therefore, in the last part of the chapter, Weinsberg's consumption practices will be treated in regard to Hogenberg's engravings, providing some new information on Hogenberg's production as well. ${ }^{5}$

\section{Biographical Information on Hermann Weinsberg}

Hermann Weinsberg was born in Cologne, where he lived and kept his Gedenkbücher. At this time, Cologne was a Catholic metropolis and the Empire's

4 Among the most recent studies: Hermann Weinsberg (1518-1597). Kölner Bürger und Ratsherr. Studien zu Leben und Werk, ed. Manfred Groten (Cologne: Böhlau Verlag, 2005), see especially the overview of the current status of research there by Tobias Wulf, 'Bestandsaufnahme und Perspektiven der Weinsberg-Forschung', pp. 35-57; Matthew Lundin, Paper Memory: A Sixteenth-Century Townsman Writes his World (Cambridge, MA and London: Harvard University Press, 2012). Furthermore, for research on foreign news, see the article by EvaMaria Schnurr on Weinsberg and the circulation of local news on the Cologne War, "Jedem anbringer gleub ich so balt nit”. Informationsbeschaffung und Mediennutzung des Kölner Bürgers Hermann Weinsberg während des Kölner Kriegs (1582 bis 1590)', Geschichte in Köln. Zeitschrift für Stadt- und Regionalgeschichte, $5^{6}$ (2009), pp. 171-206. The chapter by Gérald Chaix on religious conflict and Weinsberg does not even touch on the French Wars of Religion at all: Gérald Chaix, 'Paix de religion et concorde civique. Hermann Weinsberg, bourgeois de Cologne (1518-1597), témoin des conflits religieux', in De Michel de l'Hospital à l'édit de Nantes. Politiques et religion face aux églises, ed. Thierry Wanegffelen (ClermontFerrand: Presses Universitaires Blaise-Pascal, 2002), pp. 71-84.

5 For Franz Hogenberg's news prints consult Alexandra Schäfer, 'Les Guerres de Religion en France dans les Imprimés de l'Atelier Colonais d'Hogenberg', in Gabriele Haug-Moritz and Lothar Schilling, eds., Médialité et interprétation contemporaine des premières guerres de Religion (Berlin: De Gruyter Oldenbourg, 2014), pp. 98-121. 
largest city, a mercantile centre with a favourable geostrategic position and welldeveloped infrastructure; it was embedded in one of the large networks of handwritten news that we see reflected in the Fuggerzeitungen, enjoyed relatively lax censorship, and a large community of French- and Dutch-speaking immigrants who possessed language skills, Western connections and, not least, a significant interest in the French and Dutch Wars. All of these factors were favourable to the development of the foreign news market. ${ }^{6}$

In Cologne, Hermann Weinsberg was born in 1518 , the oldest of eleven children in a wine trader's family. His grandfather had made an impressive career, from immigrant farmhand to a city councillor. Weinsberg's father tried to cement his family's social advancement through the education of his children, and in 1543 he convinced Weinsberg to complete a law degree. However, the son only practiced the profession within the family circle, earning his living in the wine trade and through pensions instead, after several attempts to secure a steady income by ecclesiastical benefices had failed. However, his marriages to the wealthy widows Weisgin Ripgin (d. 1557) and Drutgin Barss $(d .1573)$, for whom he kept accounts, provided financial security. In 1543, when he was still a student, Weinsberg was chosen to be a councillor for the first time, after entering the gaffel Schwarzhaus. ${ }^{7}$ He held this office numerous times until his death in 1597, apart from the period 1549-65 when Weinsberg was a burgrave. ${ }^{8}$ After his mother had passed away in 1575, he lived with a brother and a sister. From 1580 onwards, as he became more and more impoverished, he was forced to take work as a night watchman at the city gates and, from $1583^{-7}$, as the captain of a patrol of soldiers. In 1597 , he died in Cologne. ${ }^{9}$

6 Cf. Wilfried Enderle, 'Die Buchdrucker der Reichsstadt Köln und die katholische Publizistik zwischen 1555 und 1648', in Der Riss im Himmel. Clemens August und seine Epoche, vol. 4: Köln als Kommunikationszentrum. Studien zur frühneuzeitlichen Stadtgeschichte, ed. Georg Mölich and Gerd Schwerhoff (Cologne: Dumont, 200o), pp. 167-82, at 169, 178; Cornel Zwierlein, Discorso und Lex Dei. Die Entstehung neuer Denkrahmen im 16. Jahrhundert und die Wahrnehmung der französischen Religionskriege in Italien und Deutschland (Göttingen: Vandenhoeck \& Ruprecht, 2006), pp. 568, 6o3; Gerd Schwerhoff, 'Handlungswissen und Wissensräume in der Stadt. Das Beispiel des Kölner Ratsherren Hermann von Weinsberg (1518-1597)', in Jörg Rogge, ed., Tradieren-Vermitteln-Anwenden. Zum Umgang mit Wissensbeständen in spätmittelalterlichen und frühneuzeitlichen Städten (Berlin: De Gruyter, 2008), pp. 61-102, esp. 65; V[iktor] Muckel, Die Entwicklung der Zensur in Köln (Würzburg: Triltsch, 1932), p. 34.

7 The gaffel is a special type of guild in Cologne.

8 In this position as a sort of municipal caretaker he received a steady income, but the office was of too low a status to allow its holder to serve as a councillor.

9 Cf. Wolfgang Herborn, 'Biographisches', in Die autobiographischen Aufzeichnungen Hermann Weinsbergs_Digitale Gesamtausgabe, <www.weinsberg.uni-bonn.de/Projekt/Weinsberg/ 


\section{The Source: Gedenkbücher}

From 1560 onwards, Weinsberg wrote his so-called Gedenkbücher, ${ }^{10}$ a mixture of reports and comments on incidents in his own life as well as on contemporary events, including foreign politics. ${ }^{11} \mathrm{He}$ began by summarising the time from his birth in 1517 to $1555 .{ }^{12}$ Weinsberg then continuously reported in a diary-like style, still drawing from his own almanac notes. These records end on 27 February 1597. As Weinsberg mentioned in the preface, he wrote the commemorative books in the style of a (fictive) confidential conversation with his potential successor as head of the Weinsberg household, in order to provide a book full of references and advice for him. ${ }^{13}$ Furthermore, the writing served as a justification of his own life and his professional decisions. Overall, he left more than 2,500 sheets, which were divided into three books: Liber iuventutis (youth: 1518-77), Liber senectutis (senior: $1578-87$ ) and Liber decrepitudinis (old age: $1588-97){ }^{14}$

Weinsberg.htm> [18/9/13]; Gabriele Jancke et al., 'Hermann von Weinsberg', in Gabriele Jancke et al., Selbstzeugnisse; Wolfgang Herborn, 'Hermann von Weinsberg (1518-1597)', in Hermann Weinsberg, pp. 15-33; Hermann Keussen, 'Weinsberg, Hermann von', in Allgemeine Deutsche Biographie, 55 (1910), pp. 18-19, <www.deutsche-biographie.de/ pnd118945408.html?anchor=adb $>$ [18/9/13].

10 A digital edition of Weinsberg's writings has made the text accessible in its entirety in an edited version for the first time: Die autobiographischen Aufzeichnungen Hermann Weinsbergs —Digitale Gesamtausgabe, <www.weinsberg.uni-bonn.de> [18/9/13]; The original manuscripts are kept in the historical municipal archive of Cologne: HAStK, Chroniken und Darstellungen (inv. 7030), Das Buch Weinsberg und Begleitmaterial (c. 1518-97), sigs. 49-51.

11 Cf. Manfred Groten, 'Zum Werk Hermann Weinsbergs', in Die autobiographischen Aufzeichnungen Hermann Weinsbergs_Digitale Gesamtausgabe, <www.weinsberg.uni-bonn .de/Projekt/Weinsberg/Weinsberg.htm> [18/9/13]; Gabriele Jancke et al, 'Hermann von Weinsberg.

12 For the earlier period Weinsberg based his writings on his own memory as well as on the stories of his relatives and friends, but included source studies and contemporary literature, too. In addition, Weinsberg had kept an almanac starting in 1550 which he used as a pool of material. Particularly for news from outside the city gates of Cologne, Weinsberg included printed historical works as well, among them Heinrich Pantaleon's translation of Johann Sleidan's comments, the Epitome published against Sleidan, Carion's chronicle and the 'Geschichtsbibel' of Sebastian Franck (cf. Groten, 'Zum Werk'; Gabriele Jancke et al., 'Hermann von Weinsberg').

13 Cf. Gregor Rohmann on the genre of the 'handbook for the head of the household': Gregor Rohmann, 'Der Lügner durchschaut die Wahrheit. Verwandtschaft, Status und historisches Wissen bei Hermann von Weinsberg', in Jahrbuch des Kölnischen Geschichtsvereins, 71 (2000), pp. 43-76, esp. 47-50.

14 Cf. Groten, 'Zum Werk'; Gabriele Jancke et al., 'Hermann von Weinsberg'; Rohmann, 'Lügner', pp. 53 and 55-6; For details on these three books (Liber iuventutis, Liber senectutis, Liber decrepitudinis), see n. 10 above. 


\section{Weinsberg's News Acquisition}

On local events, Weinsberg got his information orally, transmitted by a network of acquaintances and family members, whereas he rather infrequently received handwritten news. ${ }^{15}$ In contrast, the acquisition of foreign news, the French news, through personal contacts was extremely rare, with one exception being his nephew, Tilmann Ordenbach. Ordenbach got his doctoral degree in Valence in south-eastern France and travelled back home to Cologne via Paris, Antwerp and Maastricht (1 January 1578, ls 41v). ${ }^{16}$ From spring 1578 onwards, Tilmann Ordenbach lived in Alsace (Saverne) while he worked as a councillor for the bishop of Strasbourg, but travelled home occasionally, transporting letters between Strasbourg and Cologne (25 March 1578, ls 67r) and sending letters of news about events in France to Weinsberg as well (e.g. 17 August 1587, ls 666v; 26 November 1587, ls 686v). However, in their letters they discussed news only sporadically, writing mostly about business. ${ }^{17}$

Occasionally, Weinsberg drew upon the reports of the messengers coming to Cologne. Usually, however, he derived his knowledge of foreign news-for example on the French Wars of Religion-mainly from publicly marketed printed media, mostly pamphlets and broadsheets. ${ }^{18}$ While he regularly discussed printed news publications he used in depicting the recent foreign events in the Gedenkbücher, Weinsberg did not indicate that he might have used handwritten news publications to gain news from France. He mentions handwritten news publications only en passant as a general means for the acquisition of news. ${ }^{19}$

15 Weinsberg reported, for example, how he met a member of his gaffel who was from Antwerp. The secretary of the Prince of Orange was present, as well as several nobles from Hainault, who discussed the current events in the Netherlands (25 June 1579, ls $130 v)$.

16 Throughout the rest of the chapter, I will refer to the source by referencing the date of the entry in the Gedenkbücher, the abbreviation of the book (Liber iuventutis: li; Liber senectutis: ls; Liber decrepitudinis: ld) and the number of the paragraph cited, based on the digital edition: $<$ www.weinsberg.uni-bonn.de/ $>$ [18/9/13]. All translations into English are mine.

17 Ordenbach regularly contacted Weinsberg, e.g. 25 March 1578, ls 67r; 22 September 1581, ls 310r; 4 December 1581, ls 320r; 10 January 1582, ls 325r; 11 June 1582, ls 343v; 9 January 1583, ls 387 v; 25 March 1583, ls 397r; 27 April 1583, ls 401v; 17 August 1587, ls 666v.

18 By 'public' —in contrast to hidden, secret, and arcane - I mean the possibility in principal for everyone to access news publications (as long as they had the financial means and the ability to understand the publication).

19 Cf. Leonhard Ennen, 'Die Zeitungspresse in der Reichsstadt Köln', in Annalen des historischen Vereins für den Niederrhein, insbesondere die alte Erzdiözese Köln, 36 (1881), 
Furthermore, Weinsberg, as part of the council, was able to profit from the municipal news network as well, though he only mentioned infrequently how he profited from the municipal network for gaining news. Thanks to the official city messengers he received some news of the Franco-Dutch conflicts faster and in more detail than many other residents of Cologne. ${ }^{20}$ Finally, in addition to the printed news publications Weinsberg bought himself, oral rumours circulating in Cologne were another source, though these were of much greater importance for local than foreign news. ${ }^{21}$

In his Gedenkbücher, Weinsberg repeatedly treated the French Wars of Religion over a long period of time. However, apart from a short remark on the death of Francis II in 156o (6 December 156o, li 407r), the first news on the wars is not recorded until ${ }_{15} 67$ ( 12 October ${ }_{1567}$, li 543 ). Later on in the Gedenkbücher however, Weinsberg addressed the topic frequently.

Usually, Weinsberg started his account in the Gedenkbücher with the date of the particular event, without adding when he had received the news or when he had written his record. One exception is the peace in France between the king and the Huguenot party in 1573, of which Weinsberg noted that news had arrived on 10 July, while the peace had been agreed on 2 July. ${ }^{22}$ This indicates a lapse of eight days from the conclusion of peace at La Rochelle to the news's arrival in Cologne. However, this information is doubtful, because the initial agreement between the beleaguered Huguenots in La Rochelle and the Duke of Anjou had already been accomplished on 24June, and the lifting of the siege

pp. 12-82, esp. 20; Eva-Maria Schnurr, Religionskonflikt und Öffentlichkeit. Eine Mediengeschichte des Kölner Kriegs (1582 bis 1590) (Cologne, Weimar and Vienna: Böhlau, 2009), p. 468.

20 Cf. Schnurr, 'Informationsbeschaffung', p. 181; Religionskonflikt, p. 468; Weinsberg named a whole set of different kinds of media, e.g. news criers (1 August 1589, ld 133v), broadsheets (23 December 1588, ld 94v), travelling merchants (11 September 1582, ls 358v), a messenger and a letter to the city council (18 June 1582, ls 344v). Occasionally, Weinsberg purchased news as well by listening to news prints read out aloud (cf. Schnurr, 'Informationsbeschaffung', p. 182).

21 Cf. Schnurr, 'Informationsbeschaffung', p. 180; On rumours see: Ernst Schubert, "bauerngeschrey". Zum Problem der öffentlichen Meinung im spätmittelalterlichen Franken', in Jahrbuch für fränkische Landesforschung 34/35 (1975), pp. 883-907, esp. 883-4. Local rumours spread extremely fast in Cologne: it took only about two hours until rumours about events outside the city gates were widely discussed (in the case referenced: a Protestant service in Mechtern in 1582) (cf. Schnurr, 'Informationsbeschaffung', p. 179). On Weinsberg and local news, see the chapter 'Ein Rezipient der Publizistik des Kölner Kriegs: Das Beispiel Hermann Weinsberg', in Schnurr, Religionskonflikt, pp. 464-78. den Hugonoten gemacht sei ... Disser frit sult den 2. jul. getroffen sin". (10 July 1573, li 641r). 
happened on 6 July, and only then had the the negotiations over the exact terms of the peace begun. Therefore it seems likely that Weinsberg alluded to the agreement made on the battle field. If this was the case, the news had taken 16 days from La Rochelle to Cologne, where Weinsberg heard it on 10 July for the first time. ${ }^{23}$ As Weinsberg does not address the point, we can only speculate why he dated the agreement on 2 July.

At a later point, Weinsberg mentions a letter from Nancy addressed to the Bishop of Strasbourg, dated 5 November 1587. From Saverne, Tilmann Ordenbach passed the news of the letter to the bishop on to Weinsberg, who apparently received the news 21 days after the letter was sent. It contained news mainly from the end of October, especially about the glorious victory of Guise in Alsace on 26 October, about which Weinsberg had not yet heard one month later. ${ }^{24} \mathrm{He}$ was already accustomed to and arguably even desperate for a continual flow of news, and was not wondering if, but when news would come. $^{25}$

The question remains, however, of how Weinsberg handled this news when it became available? What was his selection criterion for the records in his Gedenkbücher?

Weinsberg judged accessible news in Cologne by its reliability, for example whether it was the first-hand testimony of eye-witnesses, accredited news reports and fresh news not hitherto confirmed. ${ }^{26}$ It appears that there were two criteria for this evaluation: firstly, how often the news was repeated (i.e. a quantitative argument), and secondly, whether it was undisputed (a qualitative argument). Following this ranking system, Weinsberg did not simply assign

23 On the postal routes news could travel more than 100 kilometres per day. Cf. Wolfgang Behringer, Im Zeichen des Merkur. Reichspost und Kommunikationsrevolution in der Frühen Neuzeit (Göttingen: Vandenhoeck \& Ruprecht, 2003), p. 104. If it was copied and translated as it seems the case with this piece of news acquired by Weinsberg, a period of 16 days seems fairly realistic.

2426 November 1587 , ls $686 \mathrm{v}-687$ r. Ordenbach reported to his relative in Cologne not only about the French Wars of Religion, but about the confessional struggle in the bishopric of Strasbourg as well (30 May 1579, ls 127v). Weinsberg sent news about the Cologne Wars to his nephew in return ( 9 January 1583 , ls $387 \mathrm{v}$ ). We cannot be sure whether Weinsberg took note of every piece of information, though this seems to be quite probable considering his vast accounts. Taking this for granted, it is striking how little news about the French Wars of Religion was actually transmitted by Ordenbach to his relative Weinsberg.

25 E.g. on the outcome of a French battle in October 1569, Weinsberg wrote: "Wie das zugangen, wirt wol in truck zukonftich pracht werden" (3 October 1569 , li $575 \mathrm{v}$ ).

2622 July 1586, ls 589v; 20 February 1588, ld 4r. Cf. Schnurr, Religionskonflikt, p. 473; Schnurr, 'Informationsbeschaffung', p. 190. 
a different degree of reliability to different media or channels of communication (oral, written/print, performative), but rather judged whether the source was credible and confirmable depending on the individual case. ${ }^{27}$

The accreditation of news was far from trivial for Weinsberg, but rather was a crucial aspect of the discussion of news. This becomes clear from the way that Weinsberg repeatedly returned to the question. It is very probable that Weinsberg was trying to educate his potential successor, for whom he wrote the Gedenkbücher, in a form of media literacy. When examining this source, it is important to keep in mind the particular social motivation that lay behind the production of the Boich Weinsberg and the Gedenkbücher. ${ }^{28}$ They provided for the burgher family Weinsberg "an inalienable patrimony, a legendary past, a deeply rooted identity, and an enduring institutional memory" usually reserved to the aristocracy, patricians or the clergy. ${ }^{29}$ If one understands his writing of the Boich Weinsberg and the Gedenkbücher as a practice to generate social status and to confirm that his family belonged to a certain social classthe elite of Cologne-it seems appropriate to suggest that being informed and exchanging news more generally were practices for acquiring social capital and thus substantiating one's belonging to a political elite. ${ }^{30}$

Weinsberg often wrote initial rumours, i.e. oral as well as printed news not yet confirmed (22 July 1586, ls $589 \mathrm{v}$ ) into a jotter, and asserted that he transcribed these exactly as heard, seen or otherwise, without adding or omitting anything. ${ }^{31}$ He would then start to ponder the credibility of the news and take its partiality into account. Only when further publications were available which supported this news item did he transfer this piece of news from his jotter into the Gedenkbücher, after some delay. In this way, he claimed to be creating a version of the recent past written to the best of his knowledge. However, at least in the Boich Weinsberg, he conceded that his knowledge depended on the circumstances and therefore demanded that his successor rewrite his notes, correct, complete,

27 E.g. 22 July 1586, ls $589 v$. Cf. Schnurr, 'Informationsbeschaffung', pp. 183 and 190-1.

28 Cf. Wulf, 'Bestandsaufnahme', p. 48; Gabriele Jancke et al., 'Hermann von Weinsberg'.

29 Cf. Lundin, Paper Memory, p. 9.

30 Cf. Glasner, 'Das erinnernde Ich'; Rohmann, 'Lügner'; also Joad Raymond's statement that news communication was a "way of developing and cementing social relationships", in 'News', in Raymond, ed., The Oxford History of Popular News Culture, vol. 1: Cheap Print in Britain and Ireland to 1660 (Oxford: Oxford University Press, 2011), pp. 377-97, at 377.

31 Cf. Schnurr, Religionskonflikt, p. 473; Schnurr, 'Informationsbeschaffung', p. 190; Peter Glasner, “Ein geschrift zu ewiger gedechtnis ..." Das erinnernde Ich bei Hermann von Weinsberg (1518-97) in der Medialität von Schrift und Bild', in Gerald Kapfhammer, ed., Autorbilder. Zur Medialität literarischer Kommunikation in Mittelalter und Früher Neuzeit (Münster: Rhema, 2007), pp. 285-320, at 293. 
shorten and improve them..$^{32}$ The impermanence of his interpretation of the past was by no means due to the quality of the sources he used:Weinsberg judged that (historical) writings based on the official documents in the chancelleries were not necessarily better informed or more authentic than less official sources, because errors and favouritism were common in both kinds of source material (20 February 1588, ld 4r).

He described the selection of news from the array of available media according to the criteria of plausibility as a person's responsibility in order to create an independent view of his own time on which later generations, especially his prospective heir, could rely (20 February 1588 , ld $4 \mathrm{r}$ ). This comment on how to handle contemporary history and news about it was clearly an allusion to his own undertaking. Weinsberg even claimed that his notes in general were model writings, designed to be imitated. ${ }^{33}$

Despite his claims to systematic procedure, Weinsberg's handling of news was rather inconsistent. Though there was a general idea behind the Gedenkbücher, Weinsberg did not pursue a writing plan. When writing, he got carried away in the process. It should not be surprising, therefore, that there are contradictions and discrepancies: Weinsberg refers explicitly to the unreliable character of some news by adding qualifying markers such as "it is said", "some people said", "rumours circulated that". ${ }^{34}$ In some cases he copies some of the news without any reference, and he rarely states from which sources the news on the French Wars of Religion derived at all. ${ }^{35}$ In contrast, Weinsberg critically noted when there was a gap ( 24 May 1568 , li $552 \mathrm{v})$, he revealed when contradictory news publications circulated in Cologne (18 June 1582, ls 344v; 26 November 1587 , ls 687 r) and he quoted false information only to comment on the untrustworthy character of those news publications. ${ }^{36}$ By openly criticising

32 Cf. Glasner, 'Das erinnernde Ich', p. 292; So far, Weinsberg's idea of historical truth as well as authenticity has been discussed above all in the context of autobiographical writing, in the Gedenkbücher as well as in the Boich Weinsberg, a partly fictional genealogical history by Weinsberg. Cf. Rohmann, 'Lügner', esp. pp. $5^{1}$ and $65^{-8}$; Wulf, 'Bestandsaufnahme', pp. 49-53; on the Boich Weinsberg, cf. Birgit Studt, 'Der Hausvater. Haus und Gedächtnis bei Hermann von Weinsberg', in Rheinische Vierteljahrsblätter, 61 (1997), pp. 135-6o.

33 Cf. Glasner, 'Das erinnernde Ich', p. 291.

34 Cf. Schnurr, 'Informationsbeschaffung', p. 180.

35 One example (24 August 1572, li 621r) is the adoption of the topical argument on the unique nature of recent events (St. Bartholomew's Day Massacre) as a typical line of argumentation in Reformed pamphlets, without Weinsberg naming his model.

36 On 24 April 1574, Weinsberg wrote that a rumour about the murder of the French king had widely circulated, which by then had already proved to be false, as Weinsberg explained (21 April 1574, li 673r). 
the unreliable character of the sources, he claimed the authorial position of a trustworthy judge and narrator, and thus enhanced the status of his writings.

On the one hand, Weinsberg clearly, if not consistently, situated himself within the news system of his time, claiming a sophisticated understanding of contemporary news media and sometimes performing critical evaluation of the news, possibly in order to serve as a model for his successor. On the other hand, he did not take up a particular position in relation to the turmoil of his time. Sticking to the news he received, Weinsberg suppressed any urge to make guesses and speculations himself, and thereby avoided expressing a clear position of his own as well. ${ }^{37}$ His self-conscious character, and an inner quarrel regarding his position as an author, seem to stand in the background.

\section{Weinsberg's Position Regarding the French Wars of Religion}

Weinsberg's writings tackle a mixture of very different topics, in which the French Wars of Religion appeared infrequently, but with some regularity. Nevertheless, Weinsberg created a degree of continuity between different pieces on the topic by occasionally referring back to things he had previously written. ${ }^{38}$ Thus, he insinuated that his interrupted narrative of the French Wars of Religion should be seen, to a certain extent at least, as a cohesive account.

Weinsberg was particularly interested in French events with an impact on his region and therefore with a certain relation to himself. ${ }^{39}$ Accordingly, the involvement of the French in the Cologne War was of enormous interest to

37 On the Cologne War, Eva-Maria Schnurr perceives similar behaviour: Weinsberg refused to take a position in the ongoing struggle, but he critically discussed the news available on recent events (cf. Schnurr, Religionskonflikt, p. 475). Weinsberg's avoidance of a clear political position has been harshly criticised in older research which tends towards a psychological judgement; Joseph Stein, for example, argued that Weinsberg was shying away from responsibility (cf. Joseph Stein, 'Über die Auswahlpublikation', in Die autobiographischen Aufzeichnungen Hermann Weinsbergs —Digitale Gesamtausgabe, <www.weinsberg.uni-bonn. de/Projekt/Weinsberg/Weinsberg.htm> [18/9/13]).

3826 November 1587 , ls 687 v: "Hie von hab ich oben fol. 666 pag. 2 wieterß gesagt und daselbst in margine".

39 Apparently, motivation for the selection of local news and foreign news did not differ in this respect: as Schnurr states concerning local events, Weinsberg was interested above all in events connected with his personal situation (cf. Schnurr, 'Informationsbeschaffung', pp. 178-9). 
Weinsberg, as was the French engagement in the Netherlands, directly across the Rhine..$^{40}$ Though he considered the conditions for French expansionism at the Rhine to be worse during his time than they had been in the wars of King Francis II of France and the Emperor Charles v, Weinsberg was convinced that the French king planned to cross the river (18 June 1582, ls 344v). Consequently, leaving aside his generally moderate attitude and neutral tone, Weinsberg clearly expressed his discontent about the French presence on the banks of the Rhine (18 June 1582, ls 344v).

While military developments and critical observations on them were clearly a significant focus (e.g. the siege of Antwerp: 7 January 1583 , ls $385 \mathrm{v}-386 \mathrm{r}$, or the intervention of the Duke of Parma: 6 May 1584, ls 452v), the news treated by Weinsberg did not exclusively contain war reports, but also concerned political and diplomatic topics, such as the strengthening of the relationship of French and Dutch Protestants through the marriage of the prince of Nassau with the daughter of Coligny (3 April 1583, ls 398r). Apparently, Weinsberg purchased news more eagerly that was connected with him personally. However, this more frequent inclusion is surely also due to the larger quantity of news on regional events that was available in Cologne, including the conflict in the Netherlands.

While Weinsberg included news on Dutch supply shortfalls resulting from the military campaign in the Netherlands (e.g. 7 January 1583 , ls $387 \mathrm{r}$ ), he treated the influence this had on the trading interests of Cologne only as a marginal aspect. ${ }^{41}$ The direct impact of the troubles in France on Cologne's long-distance trade were not discussed at all in Weinberg's notes, possibly because he did not feel that his personal economic interests were affected, though this is speculation. However, it is interesting to observe that trading interests were not a governing influence on Weinsberg's selection of news.

40 Amongst others: the involvement of the French in the skirmish near Unkel (29 August 1583 , ls $418 \mathrm{v}$ ), the hanging of a treacherous French officer cadet in Bonn (30 August 1583, ls $418 \mathrm{v}$ ), the troubles of German and French farmhands near Bonn (10 September 1583, ls 420v). For instance of the French campaigns in the Netherlands, see for example 23 July 1577, li 738r; 24 October 1577, li 745v-746r; 22 February 1582, ls 329r-or take the references to the Duke of Brabant, Francis of Alençon, the younger brother of the French king, in the Liber senectutis alone: ls $87-8$, ls 294 , ls $302-3$, ls $318-19$, ls $325-6$, ls 329 , ls 332 , ls $337-9$, ls $342-4$, ls $349^{-5} 5^{\text {, ls }} 35^{6-8}$, ls $380-2$, ls $385^{-92}$, ls $395^{-9}$, ls 411 , ls $422-6$, ls 441 , ls 451 , ls 463 , ls $474-6$, ls $487-9$, ls $667-8$.

41 At the beginning of June 1582, for example, Weinsberg reported that the Duke of Brabant (Alençon) had ordered the blocking of a shipping route, so that land-based detours were necessary. However, according to Weinsberg, this had hardly any effect on the price level (1 June 1582, ls 342v; with a different tone: 12 March 1579, ls 117v). 
The involvement of German mercenaries in France was one of the topics given preferential treatment by Weinsberg. ${ }^{42} \mathrm{He}$ mentioned that German soldiers fought on both sides (Huguenots and Royals), but gave background information only implicitly: Weinsberg observed that the territorial princes' political objectives had led to a dissociation of the German Protestant party vis-à-vis the confessional conflict in France. ${ }^{43}$

Weinsberg was not only interested in their military involvement, but also in French and German commentaries on the engagement of German soldiers and therefore-extensively, though sporadically-discussed the news publications. In 1587, for example, he debated a publication by the king of Navarre, in which an answer to the Emperor's address was included, as well as a declaration by the German officers. ${ }^{44}$ Showing critical distance, he rejected all arguments, reasoning that the war of succession was an internal French conflict, and was only entangled with other issues notably religion, inasmuch as the different parties made statements designed to attract partisans and thus to settle the conflict by force ( 26 November 1587 , ls $687 \mathrm{v}$ ).

42 See for example 12 October 1567, li 543r; 29 September 1575, li 707r; 17 August 1587, ls 666v; 26 November 1587 , ls 687 r.

43 E.g. 12 October 1567, li 543r: "Die Deutzschen deinten zu beiden seiten, herzoch Hans Wilhem van Saxen uff des koninks seiten, palzgraf Casimirus uff dess von Conde seiten".

44 The pamphlet mentioned must be: Henri, King of Navarra: Erklaerung/\| Auß was Vrsachen der || Durchleuchtigste vnnd Großmaechtigste || Koenig zu Nauarren/ des Koeniglichen Gebluets vnnd || Stammens in Franckreich ... ein außlaendisches Kriegsvolck $z u \|$ werben gedrungen worden. || ... Jtem/ kurtze Antwort auff das in Roem. Kays. Mayestat Namen besche-||henes Anbringen/ an Koen. Wuerden zu Nauarren || Gesandten/etc. Sampt einer andern Erklaerung vnd entschuldigung der Teutschen Obri-||sten ... || M. D. Lxxxvij.||; $4^{\circ}$, [16] fos. (= VD16 ZV 11386). Weinsberg paraphrased the publication: Navarre, claiming to be the heir presumptive to the French throne, had been forced into seeking support from the German mercenaries, because the Catholic party, Pope Gregory XIII and the house of Guise opposed him and maltreated the French Reformed. The German officers defended the support troops against the Emperor Rudolph II who declared them to be against the constitution and his will ("widder deß richtz constitution und ordnong sin widder irer keißrmagestat erlaubniß”). Their engagement was meant to prevent the suppression of the German princes, expected to follow the fall of Navarre. They wanted to enforce their claim regarding the open payments from the last military attack. Furthermore, German soldiers were used to working as mercenaries. As the Emperor accepted foreign soldiers in internal conflicts, he was 'advised' not to protest. The fact that Johann Casimir, the count palatine, was able to place Fabian von Dohna as leading officer in the French campaign was an annoyance for the Catholics (26 November 1587, ls $687 \mathrm{r}-687 \mathrm{v})$. 
Besides the French engagement at the Rhine near his hometown, Weinsberg discussed French events rather selectively. Peace treaties, edicts, huge battles, murder, large-scale massacres and the deaths of high-ranking people created a situational interest (e.g. St. Bartholomew's Day Massacre or the assassination of Henri III) (24 August 1572, li 62or; 1 August 1589, ld 133v). While Weinsberg concentrated on all sorts of high-level political matters 'of general interest', further selection seemed to depend on what news was accessible in Cologne rather than on specific criteria.

Weinsberg alluded to the international dimension of the conflict and the involvement of England (9 March 1573, li 629v), Spain (3 August 1586, ls 596v), Savoy (25 July 1587, ls 661r), and the papacy (9 September 1585, ls $523 \mathrm{v}$ and 26 November 1587 , ls 687 r), in addition to the Netherlands and the German princes. ${ }^{45}$

While Weinsberg generally held back personal judgements on news stories, his extensive reporting of the St. Bartholomew's Day massacre was an exception. Derogatorily, he noted King Charles' betrayal of his Huguenot subjects: "Das heischt ein Franzosichsche bruloft gehalten, das heischt sich dem konink widderstreben, das heischt legem oblivionis machen und glaub halten" ("That is what marrying is like in France, that is what it means to oppose the king, that is what it is like to make a law of amnesty and keep one's word") (24 August 1572, li 621r). In his later writings, the St. Bartholomew's Day massacre became a reference point to clarify the relationships between French protagonists and to characterise or judge behaviour. ${ }^{46}$

Weinsberg condemned all sorts of one-sided and excessive violence, no matter which religious party employed it, and discussed peace issues broadly. ${ }^{47}$ His treatment of peace issues ranged from typical rhetorical phrases of his time to a deeper interest in the concrete details of a particular

45 See respectively 9 March 1573, li 629v; 3 August 1586, ls 596v; 25 July 1587, ls 661r; 9 September 1585, ls 523v; 26 November 1587 , ls 687 r.

46 Alençon's behaviour in the Netherlands more than ten years later was compared to the events in 1572 ( 7 January 1583, ls 386v). In the context of the assassination of the Prince of Orange, Weinsberg alluded to the massacre (10 July 1584, ls 463r) and he introduced the daughter of Admiral Coligny with a reference to the infamous St. Bartholomew's Day Massacre (9 January 1584, ls 441r).

47 Cf. Wolfgang Herborn, 'Die Protestanten in Schilderung und Urteil des Kölner Chronisten Hermann von Weinsberg (1518-1598)', in Niederlande und Norddeutschland. Studien zur Regional- und Stadtgeschichte Nordwestkontinentaleuropas im Mittelalter und in der Neuzeit, ed. Winfried Ehbrecht and Heinz Schilling (Cologne and Vienna, 1983), pp. 13653 , at 141 . 
peace agreement and even to critical reflection on the core of the contemporary struggle. ${ }^{48}$

Weinsberg approached his topics pragmatically, usually basing his writing on events, though adding digressions. He tended towards an authority-friendly, pro-royal position without being openly partial (14 May 1576, li 718r). A moderate Catholic himself, Weinsberg mostly avoided confessional polemics. ${ }^{49} \mathrm{He}$ condemned the attempt to preserve the unity of faith by excessive violence. ${ }^{50}$ For the French protestants, Weinsberg used different moderately tendentious labels, from "Huguenots" to "those of the Calvinist or Reformed religion" to "adherer of the new religion" (24 August 1572, li 620v). When he wrote about the excommunication of Navarre and Condé, Weinsberg quoted Pope Sixtus V, but doubted that this step would have the desired results, especially since the leaders of the Reformed party had published an objection (9 September 1585 , ls $523 \mathrm{v})$. Besides, Weinsberg classified the participants not only by their religion: belonging to a military-political party, holding an office, being part of a court fraction, or being a partisan of an influential leader were important other strands for groupings. Weinsberg's use of these different ordering systems, however, does not always appear to be well thought through. ${ }^{51}$

48 Concerning the pacification of 1570 , for example, Weinsberg was sceptical whether the peace design was likely to guarantee a stable, long lasting peace. Sooner or later, the violent conflict would force the parties to come to a better peace agreement (11 August 1570, li 589 r). For the late period of the wars he argued that peace could only be achieved through compromise, as all parties lacked the military capacity to decide the conflict, and so religious unity was no longer a realistic option for France (26 November 1587 , ls 687v). Examples of rhetorical phrases used by Weinsberg: “God, give a good treaty" (25 November 1575, li 709v; similarly: 18 July 1585 , ls 513 r).

49 E.g. 1 January 1578, ls 32r; 25 June 1579, ls 130v; see also: Herborn, 'Hermann von Weinsberg', pp. 25-6. Weinsberg was a moderate Catholic and even owned and used books on the Roman index (Georg Witzel) (cf. Stein, 'Auswahlpublikation'). Weinsberg distanced himself from the traditional lay piety of his mother as well as the eagerly Catholic attitude of his sister-in-law (cf. Gérald Chaix, 'De la piété à la dévotion. Le conseiller de Cologne Hermann Weinsberg entre mère et belle-sœur (1518-1597)', in La religion de ma mère. Les femmes et la transmission de la foi, ed. Jean Delumeau (Paris: Les Éditions du Cerf, 1992), pp. 157-72, esp. 163-4 and 170). For a detailed examination of Weinsberg's attitude towards Protestantism cf. Herborn, 'Die Protestanten', pp. 136-53.

$5^{\circ}$ Cf. Herborn, 'Die Protestanten', p. 141.

$5^{1} \quad$ He often employed a mixture of ordering systems (12 October 1567 , li 543r): prince of Condé, i.e. the Duke of Bourbon, the Guise family, the Constable, the king, the clergy, the Italian councillors, the young French aristocracy. 
Finally, Weinberg used recent French history as an exemplum and as a source for general arguments or wise sayings. ${ }^{52}$ Thus, he implied that recent French history was general knowledge. These allusions have to be interpreted in the light of his general concern in the Gedenkbücher: Weinsberg was trying to provide comprehensive factual knowledge for his potential successor from the authoritative position as head of the household. ${ }^{53}$ By mixing historical data with his family history, Weinsberg also strategically increased the value of his account as well as his family's history and, in passing, guaranteed the continuing interest of readers. ${ }^{54}$

\section{Weinsberg as a Recipient of Hogenberg's Engravings}

Weinsberg bought engravings from the Cologne workshop of Franz Hogenberg on various occasions. In 1570, the Dutch exile Franz Hogenberg produced a series of engravings on the first three wars in France as a pirated edition of the 'Quarante Tableaux' by Jacques Tortorel and Jean Perrissin, which was published in various editions. After a long pause between 1573 and 1586, with only one sheet on France produced, the Hogenberg workshop continuously published 40 prints until the end of the French Wars of Religion in 1598.55

Weinsberg judged the prints to be trustworthy and haunting accounts of contemporary events and therefore could be used not only to inform contemporaries about the current events but also to be kept for coming generations, to show them a reliable interpretation of recent history ( 7 January 1585 , ls $486 \mathrm{v})$. Once again, it seems the author had in mind a scheme by which history acted as guiding advice for his successor. He compared the news in these publications by Hogenberg with other media; above all, with printed pamphlets and oral news, such as a report by his nephew Dr Johan Muysgin, for example. ${ }^{56}$

$5^{2} \quad$ For example, Weinsberg used the French royal dynasty to clarify his standpoint on the inheritance law (18 July 1578, ls 83v) or-in a nostalgic manner-he discussed the changes the Reformation brought with it, including the example of different territories, among them France (2 March 1584, ls 446v; similar: 29 March 158o, ls 19ov).

53 Cf. Rohmann, 'Lügner', p. 56.

54 Cf. Glasner, 'Das erinnernde Ich', p. 292.

55 For a detailed examination of the Hogenberg engravings, see: Schäfer, 'Les Guerres de Religion'.

56 Concerning the military camp of the Duke of Parma, Weinsberg compared the report of his nephew Johann Muysgin, an eyewitness who had been in the camp himself, and the engraving by Hogenberg '26.07.1586 Belagerung von Neuss durch den Herzog von Parma' 
Despite his admiration for Hogenberg, Weinsberg treated the engravings critically. Time pressure did not always allow for detailed depictions and verification of all data, but the fact that Weinsberg explicitly mentioned discrepancies in certain cases implied that the majority of the engravings were trustworthy accounts in his eyes. ${ }^{57}$ Apparently he attributed a certain evidentiary value to this visual source (eyewitness-like testimony), which he used because of their graphic quality, reliability and richness of detail. ${ }^{58}$ Weinsberg sometimes trustingly copied the verses on the sheet or other details. ${ }^{59}$

In the Gedenkbücher, Weinsberg jotted down on 4 April 1592 his largest purchase of sheets from the Hogenberg workshop, which were on the recent events in France. ${ }^{60} \mathrm{He}$ bought six engravings, concerning events from October 1591 to April 1592 (4 April 1592, ld 256v). He stated that there had not been any other publications on the French Wars of Religion in the past months. ${ }^{61}$ Apparently, Weinsberg, who was fairly interested in news from France at this

(in Franz Hogenberg-Abraham Hogenberg. Geschichtsblätter, ed. Fritz Hellwig (Nördlingen: Uhl, 1983), no. 291; cf. as well: Schnurr, 'Informationsbeschaffung', p. 186). Even though Muysgin's sayings had been confirmed by other oral sources, while the engraving by Hogenberg showed differing details, Weinsberg defended them as an equally apt interpretation of the events (21 July 1586 , ls $588 \mathrm{v}$ ).

57 At least in the case of local events, comparative accounts and eyewitness reports were easily accessible. Weinsberg reported on several occasions that discrepancies in the prints by Hogenberg were publicly discussed: 28 February 1585 , ls 492r (on the boat bridge of Antwerp): "es sagen aber die Nederlender, es sie vil anders geschaffen, dan gemailt"; 29 December 1587, ls 693r (on the capture of Bonn): "von dem Hoichberger in ein kuffern form gestechen ... Es waren etliche mit dissem gemeils und truck ubel zufriden, sprachen, Schenk het Bonn nit mit stritbar hant, dan mit verreterei ingenomen". See also: ls $586 \mathrm{v}$ (on the attack at Junkersdorf); 25 July 1586, ls 59or (on the siege of Neuss).

$5^{8}$ Cf. Schnurr, Religionskonflikt, pp. 471, 473; Schnurr, 'Informationsbeschaffung', p. 188.

59 Weinsberg wrote the name of the attacker on the Prince of Orange in the margin (10 July 1584, ls 462v): "Balthasar Serack, einem Burgundier". Following the critical digital edition of the Gedenkbücher, Weinsberg had drawn this piece of information from the print of Hogenberg, although Weinsberg only purchased the sheet for himself later.

6o Franz Hogenberg had already died in 1590, but the workshop continued publishing with his name, at first. His widow managed the officina till the son Abraham was capable to take over (cf. Ilja M. Veldman, 'Protestant emigrants. Artists from the Netherlands in Cologne (15671612)', in Künstlerischer Austausch, ed. Thomas W. Gaehtgens (Berlin: Akademie Verlag, 1993), pp. 163-74, here 166; Franz Hogenberg -Abraham Hogenberg, p. 13).

61 Examining the bibliography of books published in German-speaking countries in the sixteenth century (VD 16) however, one can determine several pamphlets published in 1591 and in the beginning of 1592 in Cologne on the French Wars of Religion, e.g. VD16 E 711; VD16 ZV 24878; VD16 ZV 22396. 
point, had tried to purchase news publications, but without success-apart from the engravings from Hogenberg's workshop. One sheet dealt with the marriage of Turenne and the capture of Astenay (27 October 1591, date of event mentioned on the sheet), another the siege of Astenay by the Duke of Lorraine (13 December 1591), the third one the punishment of Brison's treachery in Paris (19 December 1591), the fourth sheet the capture of Valéry by the Duke of Nevers (12 January 1592), the fifth one the attack on the camp of the Duke of Parma near Aumale by Henri IV (6 February 1592), while the last sheet covered the siege of Neuchâtel-en-Bray by the Duke of Parma (16 February 1592). ${ }^{62}$

Weinsberg tried to relate these six accounts of individual incidents to form a continuous narration of recent historical events (a tendency already mentioned above). Above all, he drew on the short text passages on the sheets, and only afterwards on the image, as a subsidiary source of information. ${ }^{63}$ Through narration, he constructed a coherent interpretation, reaching beyond the chronological account, using conjunctions (causal, temporal, adversative, conditional: 'here from,' 'so that', 'then', 'soon thereafter', 'but') to suggest relationships between the events, based on his own perception. On the level of content, he added information to the engravings by Hogenberg, filling the gaps. ${ }^{64}$ As he had explicitly stated that no other printed news was available, he must have gained news through other media or channels left unspecified. Nevertheless, Weinsberg added a comment on the credibility of those sources used, differentiating between news already verified and circulating rumours not yet proved. ${ }^{65}$ Concluding his description of French events on the basis of the six engravings

62 Compare Weinsberg's description (4 April 1592, ld 256v-257r) and the engravings by Hogenberg (in Franz Hogenberg - Abraham Hogenberg, nos. 75-80).

63 Concerning the engraving of the punishment of Brison, for example, Weinsberg used the text, but with different wording: "Wie monsieur Brison ein president im parlament zu Pariß sampt drien rhaidtzverwanten sich deß kreichs gedachten frei zu machen und die stadt zu laissen und die Hispanische wacht und besatzung im gefenckniß erwurgt, daruber der hertzoch von Meine in Pariß komen, die uffrurer gestraft und gefangen, also den rumor gestilt" (26 February 1592, ld 257r). Compare the engraving by Hogenberg, in Franz Hogenberg - Abraham Hogenberg, no. 77.

64 Weinsberg added, for example, after describing the sheet on the marriage of Turenne and the capture of Astenay, that Henri de La Tour d'Auvergne, the Duke of Bouillon and the count of Turenne, and his soldiers, moved to Astenay with some equipment for a siege (26 February 1592, ld 256v). He described the alternating siege of Astenay (LorraineTurenne, Navarra-Lorraine), adding that the Duke of Parma, though he had already departed on 18 November, arrived too late (26 February 1592, ld 257r).

65 "Disse zwae leste zeitung quamen zu Coln, und wart vil gesagt daß sie an einandern gewesen, aber nemanß kan etwaß gewiß sagen” (26 February 1592, ld 257r). 
Weinsberg turned from the specific recent events to a general evaluation of the current situation in France: from a military perspective, no side was potent enough to end this war (26 February 1592, ld 257r).

Weinsberg not only discussed the quality of Hogenberg's engravings as sources for recent historical or contemporary events, and based his accounts in the Gedenkbücher on those publications, but also discussed the distribution, technique, and price of the prints, as well as censorship. Hogenberg's engravings were sold in the streets of Cologne by colporteurs and in other places ("und sunst verkauft") - presumably the workshop and bookstores. They were also sent to his contacts, even in foreign countries, as with Philipp Gallus in Antwerp, in order to sell them to a wider public. ${ }^{66}$ The engravings were sold as single sheets, combined as a series, included in books and traded as albums. At first, the albums were labour-intensive and high-cost individual collections because the customers chose themselves which prints they wanted to include. ${ }^{67}$ Later, the workshop published album sets directly. ${ }^{68}$

For a series of 21 engravings Weinsberg paid " 32 a current" (i.e. albus) ${ }^{69}$ One engraving by Hogenberg must therefore have been $1.5^{2}$ albus, which was about one half or one third of the daily wage of a master craftsman or an assistant at this time in Cologne. ${ }^{70}$ Weinsberg's situation as a merchant of moderate means

6629 December 1587, ls 693r. Cf. Franz Hogenberg —Abraham Hogenberg, p. 12.

6726 February 1592, ld 257r: "Man weis die abgetruckte breif in boicher zu leimen, darin man die ganse historien und geschichten kan sehen, nimt aber vil arbeitzs und kosten".

68 Cf. Franz Hogenberg - Abraham Hogenberg, p. 5.

697 January 1585, ls 486v: "21 figuren von deß ertzstifs Coln kreich, und wie der princz van Vranien umbkomen, dar vor 32 a current bezalt". Weinsberg used "a current" usually for either gulden or albus, e.g. 31 December 1582, ls 381v; 4 January 1582, ls 324v; 4 May 1582, ls 339v; 23 June 1583, ls 410v; 6 September 1585, ls 523r; 31 December 1586, ls 543v.

70 Cf. Johann Jakob Merlo, Kölnische Künstler in alter und neuer Zeit.Johann Jacob Merlos neu bearbeitete und erweiterte Nachrichten von dem Leben und den Werken Kölner Künstler, ed. Eduard Firmenich-Richartz (Düsseldorf: Schwann, 1895), col. 375, note 1. In an order of 1561 the regular daily wage of a chiseller or carpenter was fixed: At this point 284 days per year were work days. The master earned 5 Raderalbus in summer, 4 1/2 in winter and, when the builder-owner paid his living costs, 3 Raderalbus in summer and $2 \frac{1}{2} 2$ in winter. An assistant earned and 3 Raderalbus in summer and $2 \frac{1}{2}$ in winter when he paid for his living himself (otherwise: $1 \frac{1 / 2}{2}$ Raderalbus in summer and $1 \frac{1}{4}$ in winter). One gulden was worth $5_{1}$ Albus and one Raderalbus 20 Kurantheller. As a comparative figure: in 1585 one unit of wheat cost 186,75 Albus or 2,59 gulden, whereas rye cost 130,75 Albus or 1,82 gulden (cf. Hermann Kellenbenz, 'Wirtschaftsgeschichte Kölns im 16. und beginnenden 17. Jahrhundert', in Zwei Jahrtausende Kölner Wirtschaft, vol. 1, ed. Hermann Kellenbenz (Cologne: De Gruyter, 1975), pp. 321-429, esp. 403 and 417-18; Franz Irsigler, 'Getreide- und 
proves that these prints were affordable, though too expensive for a carpenter to regularly purchase, no matter whether master or assistant, and particularly for a day labourer. However, the acquisition of a single sheet was not beyond the reach of these groups. Furthermore, discussion in the streets-above all about local events and publications concerning them-provided an alternative or additional way to receive the latest news. Weinsberg proves that the prints by Hogenberg were publicly discussed in Cologne, in terms of their reliability, for example. ${ }^{71}$

Repeatedly, Weinsberg underlined the quality of Hogenberg's publications. ${ }^{72}$ Hogenberg was among the first in Cologne who used the technique of engraving and etching and, according to Weinsberg, was an important figure in the transfer of techniques from Brabant to Cologne, a claim repeated in the chronicle Teutsche Nation Herrlichkeit (1609) by Matthias Quad, who had worked in Hogenberg's workshop for some time. ${ }^{73}$ According to Weinsberg, besides the important aspect of the technical quality of Hogenberg's work and the reliability of the content, their up-to-date nature was another point in favour of the engravings by Hogenberg. ${ }^{74}$

One would perhaps expect Hogenberg, printing as a Protestant about the crucial confessional conflicts in France and the Netherlands, to face censorship in Cologne. However, this was not the case. On both occasions where Hogenberg was confronted with censorship, municipal interests were discussed. ${ }^{75}$ Weinsberg expressed his incomprehension at the suppression of the

Brotpreise, Brotgewichte und Getreideverbrauch in Köln vom Spätmittelalter bis zum Ende des Ancien Régime', in idem, pp. 519-39, at 523).

71 On the capture of Bonn: 29 December 1587, ls 693r; On the troubles in Antwerp: 28 Feburary1585, ls 492r.

72 E.g. "gar artich stechen"; "ein herliche kunst" (26 February 1592, ld 257r).

7326 February 1592, ld 257r. Cf. Veldman, 'Protestant emigrants', 166; Ingrid von Kamptz, Civitates Orbis Terrarum. Ein Städtebuch von Georg Braun und Franz Hogenberg (Cologne, 1953), pp. 24 and 44; Concerning the role of Hogenberg for the establishment of the engraving techniques, confer as well: Wunderzeichen und Winkeldrucker 1543-1586. Einblattdrucke aus der Sammlung Wikiana in der Zentralbibliothek Zürich, ed. Bruno Weber (Zürich: U. Graf, 1972), p. 36.

74 On the occasion of the funeral of the prince of Taxis, for example, the Hogenberg workshop was able to publish his print only four days later (26 April 1588, ld 33v). Weinsberg noted furthermore that Hogenberg had published an engraving on the capture of Bonn on the 23 rd of December 1587 by the troops of Martin Schenk so quickly, that he had purchased a copy already on 29 December 1587 (29 December 1587, ls 693r).

75 This is especially transparent when the conflict of the town's authorities with the archbishop's authorities was taken up by Hogenberg: to prevent any further provocation of the archbishop of Cologne after the execution of his general commissioner Hieronymus 
print on the attack at Junkersdorf, in the light of the otherwise laxly practised censorship (15 July 1586, ls 586v). Even though the engraving had been forbidden, Weinsberg tried to view it in a bookseller's store and purchase it, but failed. However, he must have obtained access to it somehow because he quoted the text, which raises the question of efficacy of Cologne's censorship. ${ }^{76}$

\section{Conclusion}

Hermann Weinsberg's case is remarkable because he was an average burgher without any immediate, personal interests in France who commented on acquiring and handling news on the French Wars of Religion in his diary-like Gedenkbücher for about 30 years. Sources on the audience of printed media in the late sixteenth century are rare, but the case of Hermann Weinsberg can provide some insight into the practical aspects of readership.

Credibility and availability were the two main criteria for Weinsberg when purchasing news. For foreign affairs, he relied above all on printed media (broadsheets and pamphlets), chosen according to the repetitive and undisputed character of news, whereas he gathered other information only unsteadily, depending on situational personal contacts. The Hogenberg engravings which Weinsberg highly valued were both reliable and easily accessible. Accustomed to a steady influx of news already, Weinsberg documented some gaps in the flow of news.

Weinsberg showed an inconsistent handling of news in his Gedenkbücher, ranging from a critical, reflective media literacy to simple copying. Generally he provided a neutral and non-polemic account, preferring to rely on the text of the available media, trying to make sense of pieces of information by including them in a narrative framework.

Weinsberg's interest in the French Wars of Religion was triggered by personal involvement and by 'elite' affairs. On the one hand he picked political and military news with impact on his region, on German involvement in the French Wars of Religion or on questions concerning peace and stability in the

Michiels, Hogenberg had to cancel his edition treating the execution and hand in his printing plate (22 August 1587, ls 667r). See also 15 July 1586, ls 586v; and cf. also Merlo, Kölnische Künstler, col. 376; Franz Hogenberg —Abraham Hogenberg, p. 14.

76 Compare Weinsberg's note ( 15 July 1586, ls $586 \mathrm{v}$ ) with the sheet '3.7.1586 Morden bei Junkersdorf' (in Franz Hogenberg-Abraham Hogenberg, no. 290): the text corresponds, though some minor changes, especially in spelling, are visible. 
confessional struggles, while on the other hand he treated preferentially all sorts of high-level political matters in France.

Two main motivations to include news into the Gedenkbücher can be explicated: On one hand he educated his potential successor in a form of media literacy and provided comprehensive factual knowledge, on the other hand he embellished the memory of his house by including noteworthy affairs of great lords and states. 